\title{
A STUDY OF RENAL VEINS
}

\section{Bhanu Sudha Parimala Namburu*.}

Associate Professor, Department of Anatomy, N.R.I Medical College, China kakani, Guntur, District, (AP), India.

\section{ABSTRACT}

Introduction: Accessory renal arteries are more frequently reported than veins. M ultiple renal veins tend to be relatively common on the right and quite rare on the left side where as arteries have common incidence on both sides. The configuration patterns of the renal vein tributaries were classified as type IA (one upper and one lower tributary), type IB (type IA plus a posterior tributary); type IIA (more than two tributaries, for example, upper, middle and lower); type IIB (type IIA plus a posterior tributary); type III (any of the above classifications plus another additional vein).

Materials and Methods: The study was conducted during 2010 to2016, in 60 adult embalmed cadavers (60 right and 60 left kidneys) allotted for routine undergraduate dissection. Renal veins and their variations were studied and recorded carefully during dissection of retroperitoneal area.

Observations and Results: In the present study accessory renal veins were seen only on right side. Additional veins were not observed on left side. Instead, extra hilar formation of left renal vein by the union of 2 or 3 tributaries was observed. Accessory right renal vein was observed in 3 out of 60 kidneys (5\%). Extra hilar formation of left renal vein by the union of segmental renal tributaries, left supra renal vein and left gonadal vein was observed in 9 out of 60 kidneys (15\%). Left renal vein with Retro aortic course seen in 5 out of 60 (8.3\%) and circum aortic course in 2 out of 60 (3.3\%) was also observed.

Discussion and Conclusion: Incidence of accessory right renal vein was variable from $33 \%$ to as low as $0.3 \%$ in previous studies but in the present study it is $5 \%$. The cause of such variations was explained embryologically owing to the complexity in the development of renal veins along with inferior vena cava. Variations in the renal veins are clinically unpredictable but pose technical difficulty during renal transplantation. Hence the study was undertaken.

KEY WORDS: Accessory Renal Vein, Right Renal Vein, Inferior Vena Cava, Left Renal Vein, Renal Surgery.

Address for Correspondence: Dr. N. B. S. Parimala, M BBS, M. D. (Anatomy), Associate Professor, Department of Anatomy, Balaji Nivas, 48-11/8-8, currency nagar main road, Near swarna Residency Apartments, Vijayawada, Krishna district, (AP), INDIA-520008. M obile no: 9440791896 E-Mail: nbsparimala @gmail.com

\begin{tabular}{|c|c|c|}
\hline \multicolumn{3}{|c|}{ Access this Article online } \\
\hline \multirow{3}{*}{ Quick Response code } & \multicolumn{2}{|c|}{$\begin{array}{l}\text { Web site: International Journal of Anatomy and Research } \\
\text { ISSN 2321-4287 } \\
\text { www.ijmhr.org/ijar.htm }\end{array}$} \\
\hline & $\begin{array}{l}\text { Received: } 25 \text { Jul } 2017 \\
\text { Peer Review: } 25 \text { Jul } 2017\end{array}$ & $\begin{array}{l}\text { Accepted: } 05 \text { Sep } 2017 \\
\text { Published (0): } 01 \text { Oct } 2017\end{array}$ \\
\hline & Revised: None & Published (P): 01 Oct 2017 \\
\hline
\end{tabular}

\section{INTRODUCTION}

Renal vein originates from the confluence of a variable number of primary tributaries that emerge from the kidney. The cardinal venous system is represented on the right side by the vena cava itself and by the left renal vein on the opposite side. The left renal vein is longer than the right one, with the inferior vena cava in its usual position, on the right side of aorta [1].

Accessory or supernumery renal vessels are a common observation reported by many authors previously. Accordingly, accessory renal arteries tend to be twice as common as renal veins. The incidence was almost equal on both 
sides in case of arteries. Multiple renal veins were quite rare (1 percent) on the left, but relatively common (27.8 percent) on the right [2-4]. Thorough knowledge of normal and variant anatomy of renal vessels is essential in performing many retroperitoneal surgeries, venographic procedures, lymphadenectomy, renal cell cancer with venous extension, in staging of testicular tumours and placement of inferior caval filters [5].

Variations in the number of renal veins are clinically unpredictable but pose technical difficulty during renal transplantation [6].

\section{MATERIALS AND METHODS}

The present study was conducted on 60 adult human cadavers (both male and female) embalmed and allotted for routine dissection to the First M.B.B.S students of Dr. PSIMSChinnaoutipally and N.R.I Medical College Chinnakakani successively during the years 2010 to 2016. During dissection of the retroperitoneal region of abdomen, blood supply of 120 kidneys (60 right and 60 left) were studied. Renal veins and their variations including number, pattern of tributaries and course were observed carefully and recorded.

\section{OBSERVATIONS}

The venous variants seen in the present study were pre hilar tributaries of renal veins, accessory right renal veins, retro aortic and circum aortic left renal veins.

In the present study accessory renal veins were seen only on the right side. In 3/60 kidneys accessory right renal vein separately draining into inferior vena cava was observed (fig:3). Of the 3 , in 2 cases gonadal vein was a separate tributary of inferior vena cava whereas in the other it drained into lower right renal vein instead of inferior vena cava(fig :4). Triple renal veins and Accessory left renal veins were not observed in the present study.

Retro aortic (fig: 2) \& Circum Aortic left renal veins(fig:5) were observed. Prehilar anterior and posterior tributaries were seen either bilaterally or on left side(fig :1\&2). Unilateral right sided pre hilar tributaries were not seen in the present study.

Int J Anat Res 2017, 5(4.1):4463-68. ISSN 2321-4287
The configuration patterns of the RV tributaries were classified as below based on previous study[7]

Type IA -one upper and one lower tributary

Type IB - type IA plus a posterior tributary

Type IIA - more than two tributaries, for example, upper, middle and lower

Type IIB - type IIA plus a posterior tributary

Type III - any of the above classification plus another additional vein.

Fig. 1: Type 1A (left side)-pre hilar formation of left renal vein by union of two ventral tributaries.

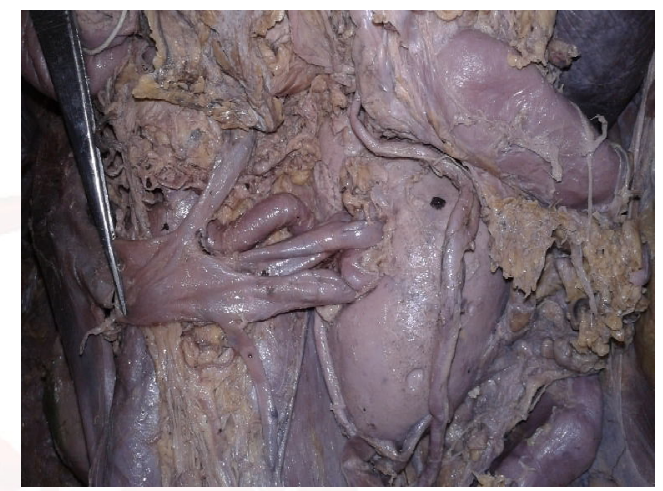

Fig. 2: Retro aortic course of left renal vein, Type1b- Pre hilar formation by union of dorsal and ventral tributaries.

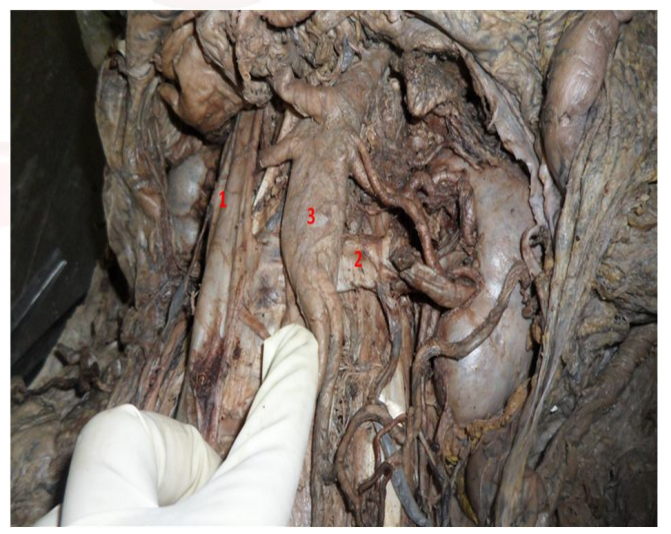

1-Inferior vena Cava, 2-Retro Aortic Left Renal Vein (type1b - pre hilar formation) 3-Abdominal Aorta.

Fig. 3: Type3 -accessory right renal vein-draining independently into inferior vena cava.

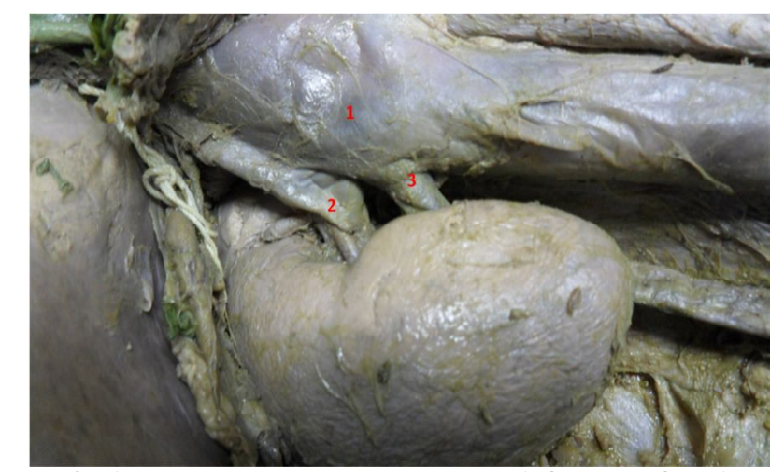

1-Inferior vena cava, 2- Upper right renal vein, 3accessory right renal vein 
Fig. 4: Type3 - accessory Right renal vein (lower one) receiving right gonadal vein.

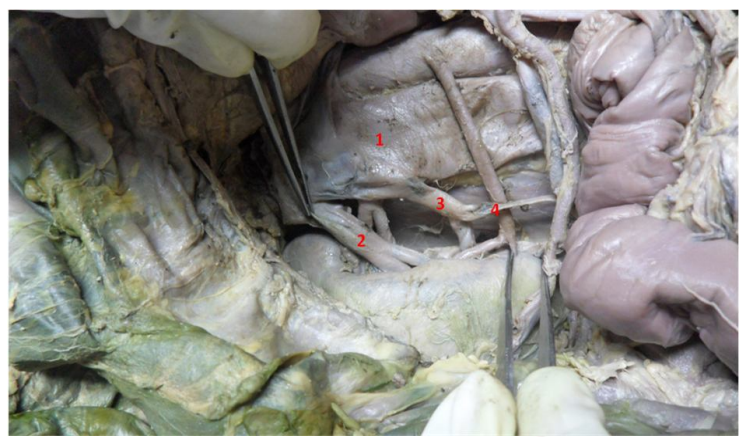

1-Inferior vena cava, 2- Upper right renal vein, 3-accessory right renal vein, 4-right testicular vein

Fig. 5: Circum Aortic Left Renal Vein.

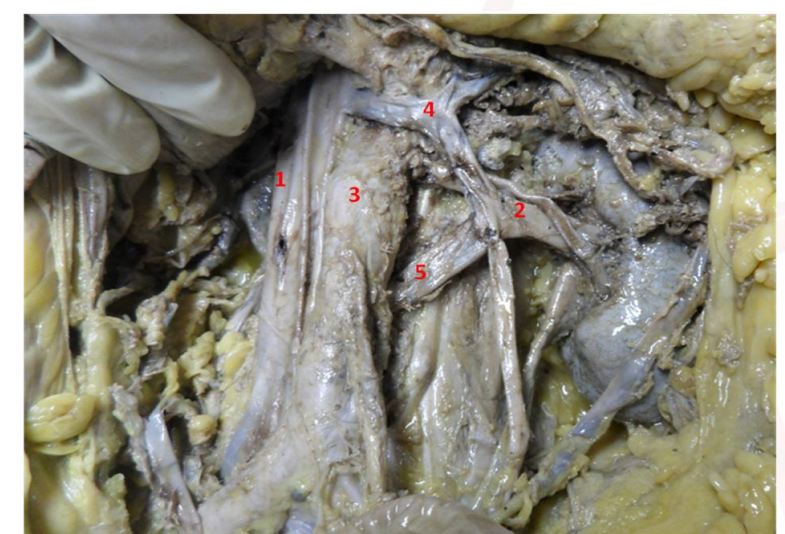

1-Inferior vena Cava, 2-Left Renal Vein, 3-Abdominal Aorta, 4-Pre Aortic limb of Circum Aortic Left Renal Vein, 5-Retro Aortic limb of Circum Aortic Left Renal Vein

Table 1: Incidence of types of renal vein tributaries in the present study.

\begin{tabular}{|c|c|c|c|c|}
\hline S.no & $\begin{array}{c}\text { Type of pre hilar } \\
\text { tributaries }\end{array}$ & $\begin{array}{c}\text { Left side } \\
(\mathbf{n = 6 0 )} \%\end{array}$ & $\begin{array}{c}\text { Right side } \\
(\mathbf{n = 6 0 )} \%\end{array}$ & Bilateral \% \\
\hline 1 & Type 1A (Fig. 1) & $2 / 60(3.3 \%)$ & - & $\begin{array}{c}2 / 60 \text { cadavers (or) } \\
4 / 120 \text { kidneys (3.3\%) }\end{array}$ \\
\hline 2 & Type 1B (Fig. 2) & $2 / 60(3.3 \%)$ & - & $\begin{array}{c}2 / 60 \text { cadavers (or) } \\
4 / 120 \text { kidneys (3.3\%) }\end{array}$ \\
\hline 3 & Type 2A & - & - & - \\
\hline 4 & Type 2B & $1 / 60(1.6 \%)$ & - & - \\
\hline 5 & Type 3 (Fig. 3,4) & - & $3 / 60(5 \%)$ & - \\
\hline
\end{tabular}

Table 2: Incidence of Left Renal Vein Anomalies in the present study.

\begin{tabular}{|c|c|c|c|}
\hline s. no & Type of variation & $\begin{array}{c}\text { No .of. } \\
\text { cases }\end{array}$ & $\%$ \\
\hline 1 & Retro aortic left renal vein (Fig. 2) & $5 / 60$ & 8.3 \\
\hline 2 & circum aortic left renal vein (Fig. 5) & $2 / 60$ & 3.3 \\
\hline
\end{tabular}

\section{DISCUSSION}

The most common venous variant seen in approximately $15-30 \%$ of individuals was Supernumerary renal veins [8].
According to Bergman et al., [4] the renal veins show less variation than do the renal arteries and multiple renal veins to be common on the right side (28\%) and rare on the left side (1\%).

A significant prevalence of anatomical variations in the left renal vein of about $92 \%$ and the presence of multiple right renal veins about 8.0 to $9.7 \%$ of cases was described in literature [9].

The cause of such variations including the origin, course $\&$ termination of renal veins can be explained on embryological basis.

A complex embryological process is responsible for the development of inferior vena cava from 3 primitive cardinal veins i.e; posterior, supra and subcardinal that appear, anastamose and regress in a sequential manner.The inferior vena cava thus developed has 4 segments called hepatic, suprarenal, renal and infrarenal of which renal and infra renal segments were the segments where abnormalities tend to occur most frequently [10].

At the time of formation of renal segment of inferior vena cava from the right sub cardinal vein due to shifting of venous arrangement, each kidney was drained by multiple mesonephric veins representing ventral and dorsal tributaries, the confluence of which resulted in the formation of corresponding renal vein. Accessory renal veins are common on the right side due to persistence of such mesonephric veins and rare on the left side as major part of the venous system regresses on that side [11].

The primary (lobar) tributaries of the renal vein, i.e. upper, middle, lower, posterior and additional renal veins (when present) were identified and used as the basis for classification. Accessory renal vein was considered as a normal variant where the extra renal vein drains into inferior vena cava separately in addition to the renal vein proper [7]. (Fig: 3, 4)

Double renal veins are commonly reported. Triple and quadruple renal veins are very rarely reported. In a study, among the 33 specimens with accessory right renal veins $28(17.9 \%)$ had two renal veins and five (3.2\%) had three of them [12].

In a study conducted on 30 cadavers (60 renal veins) supernumery renal veins were seen on right side in 10 cadavers. Nine Out of those 10 
had single right supernumery renal vein and only in one side double supernumerary veins were reported. Single supernumery left renal vein was seen [13].

In the present study double renal veins were observed only on the right side. Triple renal veins i.e.; presence of 2 accessory renal veins was not observed in this study.

Comparison of incidence of accessory renal veins (right \&left side) with previous studies was shown in Table: 3.

Table 3: Comparison of incidence of accessory renal veins (right \&left side).

\begin{tabular}{|c|l|c|c|}
\hline S.No. & \multicolumn{1}{|c|}{ Author } & $\begin{array}{c}\text { \% of accessory } \\
\text { renal veins - } \\
\text { Right side }\end{array}$ & $\begin{array}{c}\text { \% of accessory } \\
\text { renal veins- } \\
\text { Left side }\end{array}$ \\
\hline 1 & Bergman et al [4] & 28 & 1 \\
\hline 2 & Anson et al [14] & 11 & 3 \\
\hline 3 & Pick and Anson [2] & 27.8 & 1 \\
\hline 4 & Jonas Rydberg et al. [15] & 1.9 & 3.8 \\
\hline $\mathbf{5}$ & Satyapal [16] & 21.2 & 2.6 \\
\hline $\mathbf{6}$ & Dhar P and Ajmani ML [17] & 12 & 3 \\
\hline $\mathbf{7}$ & luis ernesto Ballesteros et al. [12] & 21.1 & 0.7 \\
\hline $\mathbf{8}$ & Anupma Gupta et al [13] & 33 & 3.3 \\
\hline $\mathbf{9}$ & Present Study & 6 & nil \\
\hline
\end{tabular}

The incidence of accessory right renal veins was very low in the present study when compared with previous studies.

At the hilum renal veins lie anterior to renal artery after their formation from segmental veins. The longer $(7.5 \mathrm{~cm})$ left renal vein receives two tributaries namely left suprarenal vein and left gonadal vein ,crosses the abdominal aorta superficially to open into left lateral aspect of inferior vena cava whereas the shorter right renal vein $(2.5 \mathrm{~cm})$ opens into it directly and does not receive the corresponding tributaries [18].

A rare case of three renal veins draining the right kidney and separately joining the inferior vena cava with inferior renal vein receiving right testicular vein was reported earlier [19].

Pick \& Anson [2] reported incidence of right testicular vein as a tributary of right renal vein as $15 \%$ where as in the present study only $1.6 \%$ incidence (1/60 right kidneys) (Fig: 4) was reported.

The portion of left renal vein which is associated with aorta develops from anastomoses between cardinal system of both sides in the form of a network having both pre aortic and retro aortic limbs. In case of normal left renal vein the ventral limb is retained and dorsal limb disappears, if the reverse happens it is called retro aortic left renal vein. When ventral and dorsal parts of this anastomoses persists then the resultant vein is called circum aortic left renal vein [20]. Comparison of percentage of left renal vein (LRV) variations was shown in Tab 4.

Table 4: comparison of percentage of left renal vein (LRV) variations.

\begin{tabular}{|c|l|c|c|}
\hline S.No & \multicolumn{1}{|c|}{ Author } & $\begin{array}{c}\text { Retroaortic } \\
\text { LRV- } \%\end{array}$ & $\begin{array}{c}\text { Circumaortic } \\
\text { LRV- } \%\end{array}$ \\
\hline 1 & Pick and Anson [2] & $16.80 \%$ & $3.40 \%$ \\
\hline 2 & Chuang et al [21] & $2-3 \%$ & $6-17 \%$ \\
\hline 3 & Reed et al [22] & $1.80 \%$ & $4.40 \%$ \\
\hline 4 & Trigaux et al [23] & $3.70 \%$ & $6.80 \%$ \\
\hline 5 & Dhar and Ajmani [17] & $7.80 \%$ & $4.50 \%$ \\
\hline 6 & Tatar et al [24] & $0.5 \%-6.8 \%$ & $0.3 \%-3.7 \%$ \\
\hline 7 & Anupma gupta et al [13] & $6.60 \%$ & $6.60 \%$ \\
\hline 8 & Kakros et al [25] & $0.3-1.9 \%$ & $1.5-8.7 \%$ \\
\hline 9 & Yesildag et al [26] & $0.5-6.8 \%$ & $0.3-3.7 \%$ \\
\hline 10 & Karmann et al [27] & $3.60 \%$ & $1.20 \%$ \\
\hline 11 & Aljabri et al [28] & $0.3-0.9 \%$ & $0.5-1.4 \%$ \\
\hline 12 & Present study & $8.30 \%$ & $3.30 \%$ \\
\hline
\end{tabular}

In the present study incidence of retro aortic left renal vein is comparable to that of Dhar and Ajmani [17] and that of circum aortic left renal vein with Pick and Anson [2].Unlike other studies [21-26] the incidence of retro aortic left renal vein is more than that of circum aortic left renal vein in the present study.

The retroaortic or circumaortic renal vein may be compressed between the aorta and the vertebral body, which is called posterior nutcracker. The clinical features of such phenomenon may vary from asymptomatic microhematuria to severe pelvic congestion [29].

A knowledge of the variations of renal vascular anatomy has importance in exploration and treatment of renal trauma, renal transplantation, renovascular hypertension, renal artery embolization, angioplasty or vascular reconstruction for congenital and acquired lesions, surgery for abdominal aortic aneurysm and conservative or radical renal surgery [30].

With the advent of laparoscopic renal transplantation superseding the routine open surgical method detailed and thorough knowledge of renal veins becomes essential because of the rarity of occurrence of variations, difficulty in identification, particularly when located in retro 
aortic area and the potential haemorrhage that occurs when injured during the surgical procedures[15].Hence the study was undertaken.

\section{CONCLUSION}

In the present study accessory renal veins were seen only on right side, Prehilar formation of renal vein was predominant on left side. In addition retro aortic and circum aortic course of left renal vein was also observed.

The study stresses the use of advanced non invasive radiological techniques with thorough knowledge of renal vascular anatomy. The variations of renal veins like multiple renal veins, retro and circum aortic left renal vein though uncommon should be borne in mind before radiological evaluation and any surgical procedure particularly transplantation.

\section{Conflicts of Interests: None}

\section{REFERENCES}

[1]. Hollinshed W. H. Anatomy for surgeons, $2^{\text {nd }}$ edition New York, Harper Raw publishers 1961;542-546.

[2]. Pick JW and Anson BJ. The renal vascular pedicle: An anatomical study of 430 body halves. J Urol 1940;44:411-34.

[3]. Testut, L. \& Latarjet, A. Tratado de Anatomía Humana. 8. ed. Barcelona, Salvat, 1947;4.

[4]. Bergman, R. A.; Thompson, S. A.; Afifi, A. K. \& Saadeh, F. A. Compendium of Human Anatomic Variation. Baltimore: Urban \& Schwarzenberg, 1988.

[5]. Mathews R, Smith PA, Fishman EK, Marshall FF. Anomalies of the inferior vena cava and renal veins: embryologic and surgical considerations. Urology 1999;53:873-80.

[6]. Satyapal KS, Kalideen JM , Haffejee AA, Sing B, Robbs JV, Left renal vein variations, Surg Radiol Anat, 1999;21(1):77- 81.

[7]. Satyapal KS, Classification of the drainage patterns of the renal veins, J Anat, 1995;186(Pt 2):329-333.

[8]. Kadir S. Angiography of the kidneys. In: Kadir S, ed. Diagnostic angiography. Philadelphia: Saunders, 1986; 445-495.

[9]. Baptista-Silva, J. C.; Verissimo, M. J. \& Castro, M. J.; Camara, A. L. \& Pestana, J. O. Anatomical study of the renal veins observed during 342 living-donor nephrectomies. Rev. Paul. M ed. 1997;115(3):14569.

[10]. M inniti S\& Procacci C. Congenital anomalies of the vena cava: embryological origin, imaging features and report of three new variants. European Radiology 2002;12(8):2040-2055.

[11]. Mankhause WS and Khalique A. The adrenal and renal mass and their connection with Azygos and lumber vein. J Anat .1986;146:105-15.
[12]. Iuis ernesto ballesteros,vladimir saldarriaga,luis miguel Ramirez,Autopsy material from Colombian subjects, Rom J M orphol Embryol 2014;55(1):77-81.

[13]. Anupma Gupta, Raman Gupta,Rikki Singal et al;Congenital Variations of Renal Veins: Embryological Background And Clinical Implications, Journal of Clinical and Diagnostic Research. 2011 November (Suppl-1);5(6):1140-1143.

[14]. Anson BJ, Richardson GA and Minear WL. Variations in the number and arrangement of renal vessels; a study of blood supply of four hundred kidneys. J Urol. 1936;211-19.

[15]. Jonas Rydberg,Kenyon K. Kopecky,M ark Tann, et al; Evaluation of prospective living renal donors for laparoscopic nephrectomy with multisection ct: the marriage of minimally invasive imaging with minimally invasive surgery, RadioGraphics 2001;21:S223-S236.

[16]. Satyapal KS, The renal veins: a review, Eur J Anat Suppl, 2003;7(Suppl 1):43-52.

[17]. Dhar P. and Ajmani ML. Major anomalies of left renal vein and inferior vena cava. Int M ed J. 2004; (2): Dec.

[18]. William PL, Bannister LH, Berry M M, Collins P, Dyson $M$, Dussek JE,et al. cardiovascular system. In Gray,s Anatomy 38th Ed. Churchill Livingstone Edinburg 1995:1547.

[19]. R. M. P. Fernandes; F. H. P. Conte et al; Triple right renal vein: an uncommon variation Int. J. M orphol., 23(3):231-233, 2005.

[20]. Kahn PC. Selective venography of the branches In: Ferris EJ, Hipona FA, Kahn PC, et al. eds. Venography of the inferior vena cava and its branches. Huntington: Krieger, 1973;154-224.

[21]. Chuang VP, M ena CE, Hoskins PA. Congenital anomalies of the left renal veins: Angiographic consideration. Br J Radiol 1974;47:214-8.

[22]. Reed M D, Friedman AC, Nealey P. Anomalies of the left renal vein: analysis of 433 CT scans. J Comput Assist Tomogr 1982;6:1124-6.

[23]. Trigaux JP, Vandroogenbroek S, De Wispelaere JF, Lacrosse $M$, Jamart J. Congenital anomalies of the inferior vena cava and left renal vein: evaluation with spiral CT. J Vasc Interv Radiol.1998;9:339-45

[24]. Tatar I, Tore HG, H. Hamidi Celik and Karcaaltincaba $M$. Retro aortic and Circumaortic left renal veins with their finding and review of the literature. Anatomy.2008; 2:72-6.

[25].KarkosCD,Bruce IA,Thomson G], Lambert $M$ E.Retroaortic left renal vein \&its implications in abdominal aortic surgery. AnnVasc Surg 2001;15:703-8.

[26]. Yesildag A, Adanir E, Koroglu M, Baykal B, Oyar O, Gulsoy UK. Incidence of left renal vein anomalies in routine abdominal CTscans. Tani Girisim Radyol 2004; 10: 140-3.

[27]. Karaman B, Koplay M, Ozturk E, Basekim CC, Ogul $H$, Mutlu $H$, et al. Retroaortic left renal vein: multidetector computed tomography angiography findings and its clinical importance. Acta Radiol 2007; 48:355-60. 
[28]. Aljabri B, M cDonald PS, Satin R, Stein LS, Obrand DI $\&$ Steinmetz OK. Incidence of major venous and renal anomalies relevant to aortoiliac surgery as demonstrated by computed tomography. Annals of Vascular Surgery 2011;15(6):615-618.

[29]. Andrew KK, Thom WR. Nutcracker phenomenon and nutcracker syndrome. M ayo Clin Proc 2010; 85:5529.
[30]. Sampaio, F. J. \& Aragao, A. H. M. Anatomical relationship between the renal venous arrangement and the kidney collecting system. J. Urol., 1990;144:1089-93.

\author{
How to cite this article: \\ Bhanu Sudha Parimala Namburu. A STUDY OF RENAL VEINS. Int J \\ Anat Res 2017;5(4.1):4463-4468. DOI: 10.16965/ijar.2017.375
}

